Bangladesh J. Plant Taxon. 26(2): 157-168, 2019 (December)

(C) 2019 Bangladesh Association of Plant Taxonomists

\title{
POLLEN MORPHOLOGY AND ITS SYSTEMATIC IMPLICATION ON SOME SPECIES OF ARTEMISIA L. FROM GILGIT-BALTISTAN PAKISTAN
}

\author{
Adil Hussain*, Daniel Potter ${ }^{1}$, Muhammad Qasim Hayat ${ }^{2}$, \\ Sumaira SAHREEN ${ }^{3}$ AND Syed Ali IMRAN BoKHARI \\ Department of Biological Sciences, International Islamic University Islamabad, \\ 44000 Pakistan
}

Keywords: Artemisia; Asteraceae; Pollen morphology; Taxonomy; Gilgit-Baltistan; Pakistan.

\begin{abstract}
This study was accomplished to scrutinize the pollen morphology of 15 species of the genus Artemisia of the family Asteraceae from Gilgit-Baltistan region of Pakistan by means of scanning electron microscopy (SEM). Results revealed pollen grains of Artemisia species with tricolporate shape, and characterized by globular symmetry (ellipsoid ball shaped from equatorial side and three lobed rounds from polar view) with few exceptions. Additionally, the pollens are marked with reduced spinules on their surfaces which are diagnostic character for the genus Artemisia. In this study, seven micromorphological characters of pollen grains of 15 Artemisia species viz. shape of pollen, arrangement of spinules, exine sculpture, spinules base, equatorial width and polar length, were employed to construct a dendrogram following the consequential cluster analyses. In the dentrogram, four groups within the studied Artemisia species have been recognized. The pollen morphology of Artemisia could be a good taxonomic marker to cope with its taxonomic delimitations in combination with other floral and molecular attributes.
\end{abstract}

\section{Introduction}

The genus Artemisia L. (Asteraceae) possesses five hundred species in the form of herbs and shrubs (Valles and McArthur, 2001). It is a diverse genus of the tribe Anthemideae of family Asteraceae (Martin et al., 2003).

Some Artemisia species have a remarkable economic status due to their antitumor, antispasmodic, antimicrobial, antiseptic, antimalarial, hepato-protective and antirheumatic activities (Terra et al., 2007; Hussain et al., 2017).

The basis of taxonomy of Artemisia is its capitular morphology (Watson et al., 2002). For example, the ray florets in section Seriphidium Besser ex Hook are reduced to a membranous vestige. Its capitulum is without ray florets and only possesses the hermaphrodite disc florets. Hence, this capitulum is homogamous. The capitulum in other subgenera (Abrotanum Besser, Dracunculus Besser, Absinthium Mill., Artemisia L.) have two types of florets: hermaphrodite or staminate disc florets and ray pistillate florets and this capitulum becomes heterogamous (Bremer and Humphries, 1993).

The taxonomy of this diverse genus is unresolved for many years. It has been years when taxonomists conducted investigations (Bremer and Humphries, 1993; Kornkven et al., 1998, 1999; Torell et al., 1999; Watson et al., 2002; D’Andrea et al., 2003; Vallès et al., 2008; Sanz et al., 2008; Pellicer et al., 2010; Garcia et al., 2011; Riggins and Seigler, 2012; Haghighi et al., 2014;

*Corresponding author E-Mail. adil.phdbt31@iiu.edu.pk

${ }^{1}$ Department of Plant Sciences, College of Agricultural and Environmental Sciences, University of California Davis, 95616 US.

${ }^{2}$ Department of Plant Biotechnology, Atta-ur-Rahman School of Applied Biosciences, National University of Sciences and Technology Islamabad, 44000 Pakistan.

${ }^{3}$ Botanical Sciences Division, Pakistan Museum of Natural History Islamabad, 44000 Pakistan. 
Malik et al., 2017; Hussain et al., 2019b) on this single large genus with 500 species (Torrell et al., 1999; Martin et al., 2003) and recognized its six subgenera namely Dracunculus Besser, Artemisia Tourn., Absinthium (Mill.) Less., Tridentatae (Rydberg) McArthur, Seriphidium (Besser) Poljakov and Pacifica Hobbs. \& Baldwin. In few investigations, the subgenera Artemisia and Absinthium were merged under one subgenus Artemisia (Shultz, 2009) while subgenera Seriphidium was separated for the genus Artemisa in former studies of Bremer and Humphries (1993), Bremer (1994), Ling (1995) and Ghafoor (2002).

Researchers have approved that the critical anatomical analysis of rarer morphological features with molecular phylogenies are fruitful and this combination could become a power tool to resolve taxonomic issues (Scotland et al., 2003; Perveen and Qaiser, 2010) especially the pollen morphology in specific and generic levels of classification of Asteraceae family (Zafar et al., 2007). The significance of pollen morphology in plant systematics has been authenticated by various researchers. Palynological study has been utilized to indicate relationships among the different taxa of Asteraceae family (Mallick, 2015). Stuessy (2009) stated that the data from pollen grains are known to be useful at all levels of the taxonomic hierarchy, and can be helpful in suggesting a relationship.

In earlier investigations, Edward (1994) proposed two types of pollen structure in Asteraceae namely, the caveate and the anthemoid. The anthemoid type was primarily used for the pollen grains of Anthemideae. The anthemoid type of pollen grains contains the basal columellae rising from the foot layer, and one or many shorter layers columellae. There are internal tecta which are present above the basal columellae. While the caveate grains have only internal cavity without basal columellae.

In the subtribe Anthemideae, studies based on pollen data confirmed the presence of two major patterns of pollen. These patterns are essential taxonomic characters in Artemisia and its closely related genera, i.e. one genus with long spinules (Anthemis) and the other with short spinules (Artemisia). It could be authenticated that short spinules in the pollen were evolved from long spinules of pollen on the basis of their order of occurrences in the geological past (Martín et al., 2003).

In the genus Artemisia, investigation of pollen morphology has been started from the time of Wodehouse (1926). The following workers such as Valles et al. (1987), Caramiello et al. (1989), Lodari et al. (1989), Vezey et al. (1994), Martin et al. (2003), Jiang (2005), and Hayat et al. (2010) elaborated the taxonomic importance with different perspectives of the characteristics of Artemisia pollens including the structural organization, shape and size, diversity of sculpture in exine, magnitudes of exine aperture etc.

Nevertheless, there is a little information available on the pollen morphology of the genus Artemisia, most especially from the north region of Pakistan. This study provides important data on the micromorphological features of pollen grains of some species of the genus Artemisia from Gilgit-Baltistan region of Pakistan in order to establish their availability for future taxonomic works. The cluster analysis of these data gives an understanding on the putative relationships among the species of this genus.

\section{Materials and Methods}

\section{Study area}

Gilgit-Baltistan region of Pakistan bears a diverse climate and this region is well-known for housing an immense biodiversity of plants. This region is located between latitude $35^{\circ}$ to $37^{\circ}$ East and longitude $72^{\circ}$ to $75^{\circ}$ North, and has seven districts namely, Gilgit, Baltistan, Ghizar, Ganche, Hunza Nagar, Astore and Diamer. Samples of Artemisia species for pollen study were collected 
during extensive field surveys over a period of two years (2016-2017) in different areas of GilgitBaltistan as already given in our preceding papers (Hussain et al., 2019a,b).

\section{Pollen material}

The pollen material employed in this study was obtained from herbarium specimens as well as from fresh samples collected from different regions of Gilgit-Baltistan of Pakistan. The details of origin and collection of studied Artemisia species have been provided in Table 1. Primarily, the pollen grains of Artemisia species were prepared for scanning electron microscopy (SEM) by the standard methods described by Hayat et al. (2010) and Perveen and Qaiser (2010). To separate the pollen grains from anthers, stereo microscope was used.

Table 1. Collection details of Artemisia species employed in the present study from Gilgit-Baltistan region of Pakistan.

\begin{tabular}{|c|c|c|c|c|c|c|}
\hline Taxa & Latitude & Longitude & Location & $\begin{array}{l}\text { Voucher } \\
\text { specimen no }\end{array}$ & Collectors & Date \\
\hline Artemisia anпиа $\mathrm{L}$. & N-35'54.949 & E-74'18.508 & $\begin{array}{l}\text { Barmas Paen } \\
\text { Gilgit }\end{array}$ & PMNH-41582 & $\begin{array}{l}\text { Adil Hussain } \\
\text { and Tanseer }\end{array}$ & 24-06-2016 \\
\hline A. austriaca (Vaill.) L. * & N-36'01.609 & E-74'33.255 & $\begin{array}{l}\text { Bagrote Valley } \\
\text { Gilgit }\end{array}$ & PMNH-41643 & $\begin{array}{l}\text { Adil Hussain } \\
\text { and Tabeer }\end{array}$ & $15-08-2016$ \\
\hline A. chamaemelifolia Vill.* & N-36'09.622 & E-74'11.622 & $\begin{array}{l}\text { Naltar Valley } \\
\text { Gilgit }\end{array}$ & PMNH-41630 & $\begin{array}{l}\text { Adil Hussain } \\
\text { and Tanseer }\end{array}$ & 04-08-2016 \\
\hline A. chinensis L.* & N-35'26.585 & E-75'27.011 & $\begin{array}{l}\text { Shangrilla } \\
\text { skardu }\end{array}$ & PMNH-41722 & $\begin{array}{l}\text { Adil Hussain } \\
\text { and Tanseer }\end{array}$ & $02-10-2017$ \\
\hline A. campestris $\mathrm{L}$. & N-36'08.708 & E-74'12.397 & $\begin{array}{l}\text { Naltar Valley } \\
\text { Gilgit }\end{array}$ & PMNH-41619 & $\begin{array}{l}\text { Adil Hussain } \\
\text { and Tabeer }\end{array}$ & 02-08-2016 \\
\hline A. gmelinii Weber ex Stech. & N-36'08.967 & E-74'12.112 & $\begin{array}{l}\text { Naltar Valley } \\
\text { Gilgit }\end{array}$ & PMNH-41621 & $\begin{array}{l}\text { Adil Hussain } \\
\text { and Tanseer }\end{array}$ & 02-08-2016 \\
\hline A. herba-alba Asso. & N-35'54.061 & E-74'12.762 & $\begin{array}{l}\text { Kargah Nala } \\
\text { Gilgit }\end{array}$ & PMNH-41599 & $\begin{array}{l}\text { Adil Hussain } \\
\text { and Tanseer }\end{array}$ & $25-07-2016$ \\
\hline A. indica Willd. & N-36'15.250 & E-73'24.240 & Yasin Ghizer & PMNH-41694 & $\begin{array}{l}\text { Adil Hussain } \\
\text { and Amar }\end{array}$ & $11-08-2017$ \\
\hline A. maritima L. Ex Hook $\mathrm{f}$ & N-35'52.660 & E-74'25.594 & $\begin{array}{l}\text { Minawar } \\
\text { Gilgit }\end{array}$ & PMNH-41616 & $\begin{array}{l}\text { Adil Hussain } \\
\text { and Tanseer }\end{array}$ & $31-07-2016$ \\
\hline A. montana Pamp.* & $\mathrm{N}-35 ' 30.883$ & E-75'40.115 & $\begin{array}{l}\text { Hashupi } \\
\text { Shigar Skardu }\end{array}$ & PMNH-41708 & $\begin{array}{l}\text { Adil Hussain } \\
\text { and Tanseer }\end{array}$ & $28-08-2016$ \\
\hline A. pontica L.* & N-36'02.121 & E-74'35.227 & $\begin{array}{l}\text { Bagrote Valley } \\
\text { Gilgit }\end{array}$ & PMNH-41642 & $\begin{array}{l}\text { Adil Hussain } \\
\text { and Tanseer }\end{array}$ & $14-08-2016$ \\
\hline A. rutifolia Var. & N-36'08.708 & E-74'12.397 & $\begin{array}{l}\text { Naltar Valley } \\
\text { Gilgit }\end{array}$ & PMNH-41618 & $\begin{array}{l}\text { Adil Hussain } \\
\text { and Tanseer }\end{array}$ & 02-08-2016 \\
\hline A. scoparia Waldst. \& Kit.* & N-35'26.665 & E-75'26.960 & $\begin{array}{l}\text { Kachura Lake } \\
\text { Skardu }\end{array}$ & PMNH-41714 & $\begin{array}{l}\text { Adil Hussain } \\
\text { and Tanseer }\end{array}$ & $30-08-2016$ \\
\hline A. tournefortiana Rachb. & N-35'25.493 & E-75'44.507 & $\begin{array}{l}\text { Shigar Valley } \\
\text { Skardu }\end{array}$ & PMNH-41704 & $\begin{array}{l}\text { Adil Hussain } \\
\text { and Tanseer }\end{array}$ & $27-08-2016$ \\
\hline A. vulgaris $\mathrm{L}$. & N-36'20.508 & E-74'52.277 & $\begin{array}{l}\text { Shishkat } \\
\text { Hunza Nagar }\end{array}$ & PMNH-41646 & $\begin{array}{l}\text { Adil Hussain } \\
\text { and Tanseer }\end{array}$ & $10-07-2016$ \\
\hline
\end{tabular}

The voucher specimen numbers for each species have been obtained from Pakistan Museum of Natural History (PMNH) Islamabad Pakistan. * Rare Artemisia species from Gilgit-Baltistan region of Pakistan

\section{Scanning electron microscopy (SEM)}

For SEM analysis, the pollen grains were acetolysed and directly transferred to the sticky carbon disc on metal stub and coated with platinum in a sputtering chamber (Pelco Auto sputter Coater SC-7, Ted Pella Inc). Philips XL30 TMP (FEI Company) electron microscope was used to 
analyze the samples at 5, 10 and $20 \mathrm{kV}$ (Hussain et al., 20019a), at the core electron microscopy core laboratory, Tupper Hall, University of California Davis California USA.

\section{Light microscopy (LM)}

Micromorphological observations of pollen grains were done with OLYMPUS/BX-51 light microscope at Department of Plant Sciences, University of California Davis California USA. Observations for equatorial diameter $(\mathrm{E})$, polar diameter $(\mathrm{P})$ and $\mathrm{P} / \mathrm{E}$ ratio were taken according to Reitssma (1970) and Hayat et al. (2010).

\section{Cluster analysis}

A data matrix was generated from the recorded micromorphological characteristics of the pollens of Artemisia. This data matrix was then employed for cluster analysis by means of UPGMA method with EUCLIDEAN in the MVSP software version 3.21 (Kovach, 2007).

\section{Results and Discussion}

In this study, the characteristics of pollen of 15 Artemisia species have been examined in detail using scanning electron microscopy. Results of this study found some variation in the pollen structure of the investigated Artemisia species. The characteristics of pollen includes equatorial (E) and polar (P) measurements, polar and equatorial ratio $(\mathrm{P} / \mathrm{E})$, pollen shape, spinules presence/absence and the ornamentation of exine. The quantitative characteristics of the examined species are given in Table 2 and SEM micrographs on pollen structures are presented in Figs 1-3. The equatorial and polar views of the Artemisia pollen are given in Figs 1 and 2, respectively. The sculpture of exine surface of Artemisia pollens are evident from Fig. 3, where the presence of tiny spinules can also be seen. Similarly in the spinule densities was varied among different species of Artemisia. These spinules are very unique in all investigated Artemisia species. Few investigated species showed some degenerative tendency in their structure. For example, the spinules in $A$. chinensis were found to be loosely arranged (Fig 3i) as compared to the spinules of other Artemisia species pollen (Fig. 3).

Table 2. Quantitative characteristics of pollen of different Artemisia species from Gilgit-Baltistan region of Pakistan.

\begin{tabular}{llll}
\hline Taxa & Polar $(\mu \mathrm{m})$ & Equatorial $(\mu \mathrm{m})$ & P/E Sphericity \\
\hline Artemisia annua & 15.60 & 18.79 & 0.83 \\
A. austriaca & 17.20 & 16.49 & 1.04 \\
A. campestris & 15.55 & 15.75 & 0.98 \\
A. chamaemelifolia & 20.30 & 19.04 & 1.06 \\
A. chinensis & 24.24 & 12.01 & 2.01 \\
A. gmelinii & 16.86 & 14.90 & 1.13 \\
A. herba-alba & 22.58 & 18.64 & 1.21 \\
A. indica & 17.65 & 14.37 & 1.22 \\
A. maritima & 15.59 & 14.49 & 1.07 \\
A. montana. & 15.45 & 16.54 & 0.93 \\
A. pontica & 17.86 & 14.65 & 1.21 \\
A. rutifolia & 16.70 & 17.43 & 0.95 \\
A. scoparia & 15.12 & 17.36 & 0.87 \\
A. tournefortiana & 19.08 & 19.59 & 0.97 \\
A. vulgaris & 15.33 & 16.93 & 0.90 \\
\hline
\end{tabular}




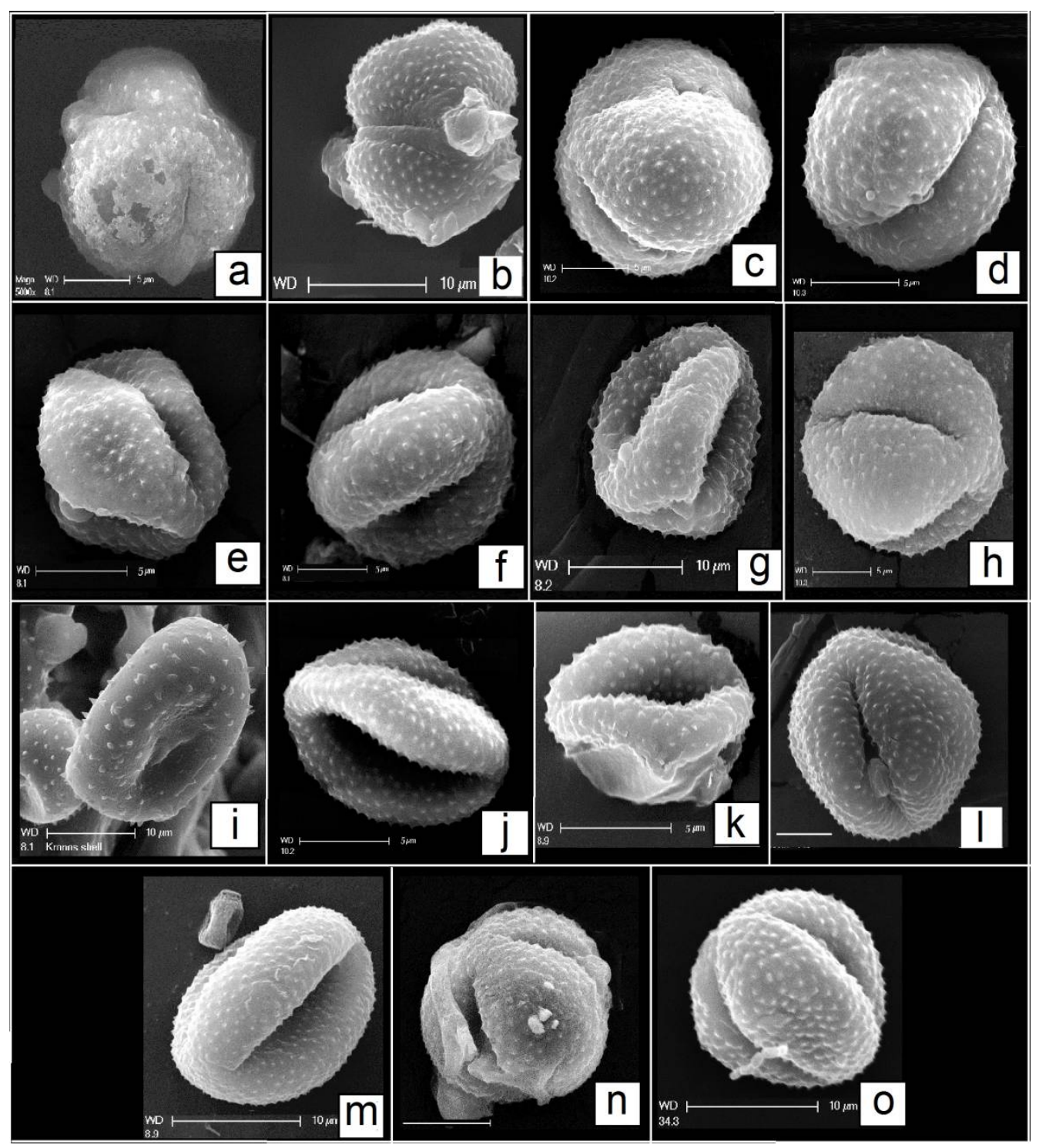

Fig. 1. Scanning electron micrographs showing the equatorial view of pollens of Artemisia species: a, $A$. annua; b, A. maritima; c, A. rutifolia; d, A. campestris; e, A. chamaemelifolia; f, A. tournefortiana; g, A. indica; h, A. scoparia; i, A. chinensis; j, A. austriaca; k, A. gmelinii; 1, A. herba-alba; m, A. pontica; n, A. vulgaris; o, A. montana. Scale bar $=2-10 \mu \mathrm{m}$.

From LM and SEM observations, the shape of pollen grain was found to be homogeneous with few exceptions throughout the genus and confirms the monophyly of genus Artemisia (Hayat et al., 2010) as presented the monophyly of Artemisia in molecular studies of Torrell et al. (1999), Watson et al. (2002), Hussain et al. (2019a,b). The general features of Artemisia pollen recorded in the present study are in high concordance with Jiang (2005) and Hayat et al. (2010) who found approximate symmetry or globular, 3 lobed spheres in the equatorial view while ellipsoid in the polar side with tricolporate structure in different species of Artemisia. 

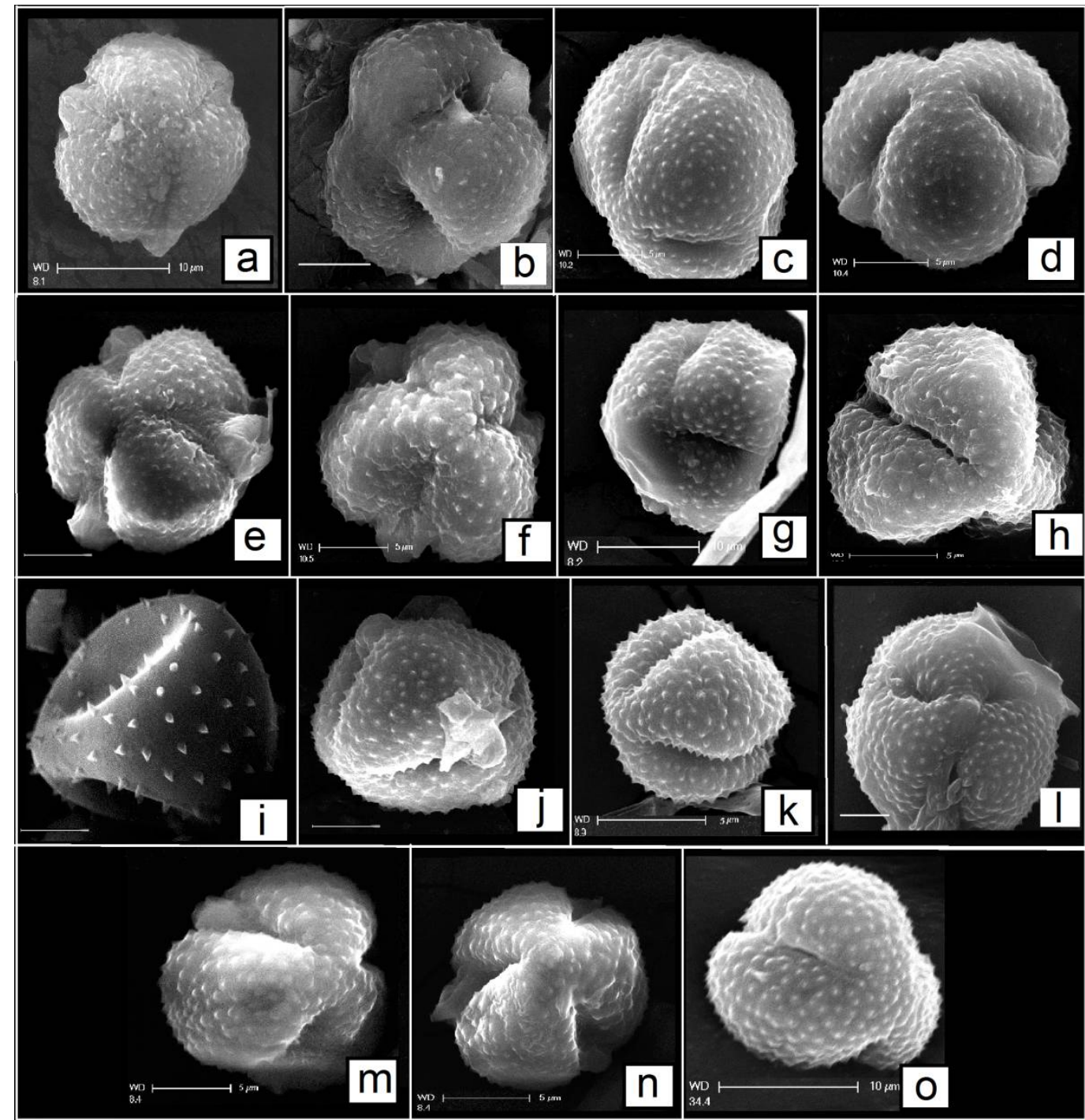

Fig. 2. Scanning electron micrographs showing the polar view of pollens of Artemisia species: a, A. annua; b, A. maritima; c, A. rutifolia; d, A. campestris; e, A. chamaemelifolia; f, A. tournefortiana; g, A. indica; h,

A. scoparia; i, A. chinensis; j, A. austriaca; k, A. gmelinii; 1, A. herba-alba; m, A. pontica; n, A. vulgaris; o, A. montana. Scale bar $=2-10 \mu \mathrm{m}$.

Pollen characteristics among the investigated species look similar except in Artemisia chinensis. The division of the genus Artemisia into subgenera by means of floral morphology and molecular studies could not be recognized by pollen data, because the pollen morphology of the species investigated is very similar in shape, size as well as in exine sculpture with few exceptions. The family Asteraceae is eurypalynous, and the genera of this family possess zonocolporate type of pollen (Sachdeva and Malik, 1986). An important character of pollen is spine present in the exine that can be utilized as diagnostic character in the genera of Asteraceae (Pinar and Donmez, 2000). On the other hand, the morphology of pollen of different Asteraceae 
genera previously investigated showed that the exine feature of pollen is very significant in taxonomy and classification based on phylogeny (Mbagwu and Edeoga, 2006). This study also validates that the spinule present in Artemisia pollen is very crucial marker for species delimitation and classification.

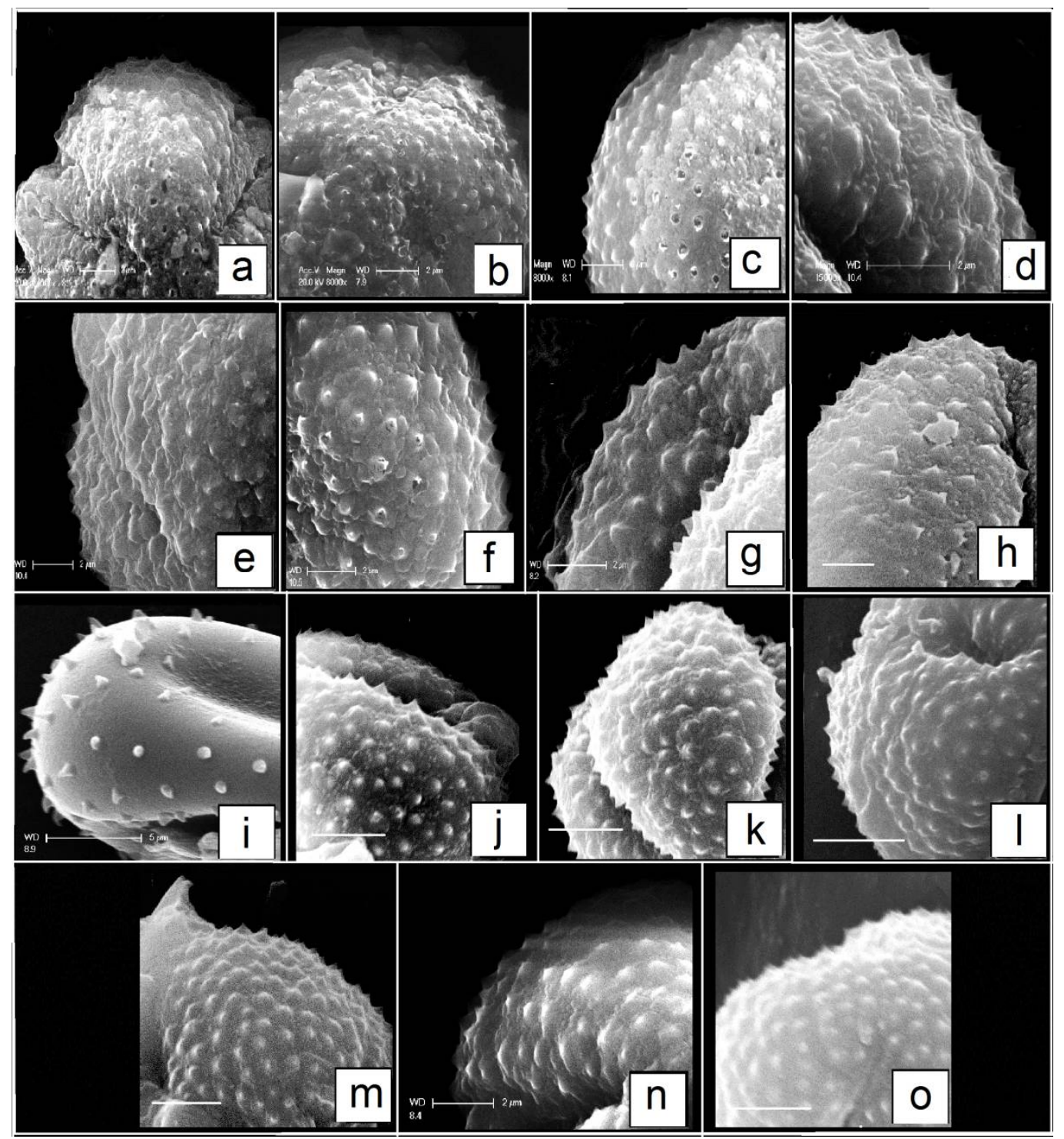

Fig. 3. Scanning electron micrographs showing the exine sculpture view of pollens of Artemisia species: a, $A$. annua; b, A. maritima; c, A. rutifolia; d, A. campestris; e, A. chamaemelifolia; f, A. tournefortiana; g, A. indica; h, A. scoparia; i, A. chinensis; j, A. austriaca; k, A. gmelinii; 1, A. herba-alba; m, A. pontica; n, A. vulgaris; o, A. montana. Scale bar $=2-10 \mu \mathrm{m}$. 
A total of seven micromorphological characters of the pollens of different Artemisia species, studied by LM and SEM, were selected for cluster analysis using UPGMA (Table 3). The data matrix based on pollen features of different Artemisia species used for cluster analysis is provided in Table 4.

Table 3. Pollen characters and character states for the cluster analysis of Artemisia. The numbers in brackets are the codes for character states. The code of plesiomorphic character state is always 0 .

\begin{tabular}{lll}
\hline Sl. No. & Characters & Character states \\
\hline 1 & Pollen type & Anthemis $(0)$, Artemisia $(1)$ \\
2 & Pollen shape & Globular (0), Oblate (1) \\
3 & Spinules arrangement & Dense (0), Loose (1) \\
4 & Exine sculpture & Granular (0), Sinuolate (1) \\
5 & Spinules base & Stretching and outward extending (0) Normal* (1) \\
6 & Polar length & $>26 \mu \mathrm{m}(0),>23-26 \mu \mathrm{m}(1),>22-23 \mu \mathrm{m}(2)$, \\
& & $>21-22 \mu \mathrm{m}(3),>20-21 \mu \mathrm{m}(4),>19-20 \mu \mathrm{m}(5)$, \\
& & $>18-19 \mu \mathrm{m}(6),>17-18 \mu \mathrm{m}(7), 16-17 \mu \mathrm{m}(8), 15-16 \mu \mathrm{m}(9)$ \\
7 & Equatorial width & $>21 \mu \mathrm{m}(0),>20-21 \mu \mathrm{m}(1),>19-20 \mu \mathrm{m}(2)$, \\
& & $>15-19 \mu \mathrm{m}(3),>17-18 \mu \mathrm{m}(4),>16-17 \mu \mathrm{m}(5), 14-15 \mu \mathrm{m}(7)$ \\
\hline
\end{tabular}

Table 4. Data matrix used in cluster analysis of Artemisia species based on pollen features.

\begin{tabular}{lllllllll}
\hline S1. No. & Taxa & 1 & 2 & 3 & 4 & 5 & 6 & 7 \\
\hline 1 & A. annua & 1 & 1 & 0 & 1 & 1 & 9 & 3 \\
2 & A. austriaca & 1 & 1 & 1 & 0 & 0 & 7 & 5 \\
3 & A. campestris & 1 & 0 & 1 & 1 & 0 & 9 & 6 \\
4 & A. chamaemelifolia & 1 & 1 & 0 & 1 & 1 & 4 & 2 \\
5 & A. chinensis & 1 & 1 & 1 & 0 & 1 & 1 & 1 \\
6 & A. gmelinii & 1 & 1 & 0 & 1 & 1 & 8 & 7 \\
7 & A. herba-alba & 1 & 1 & 1 & 0 & 1 & 9 & 7 \\
8 & A. indica & 1 & 1 & 1 & 1 & 1 & 7 & 7 \\
9 & A. maritima & 1 & 1 & 1 & 0 & 1 & 9 & 3 \\
10 & A. montana & 1 & 0 & 0 & 0 & 1 & 9 & 5 \\
11 & A. pontica & 1 & 1 & 0 & 0 & 1 & 7 & 7 \\
12 & A. rutifolia & 1 & 0 & 1 & 0 & 0 & 8 & 4 \\
13 & A. scoparia & 1 & 0 & 1 & 1 & 0 & 9 & 4 \\
14 & A. tournefortiana & 1 & 1 & 1 & 1 & 1 & 5 & 2 \\
15 & A. vulgaris & 1 & 0 & 0 & 1 & 0 & 9 & 5 \\
\hline
\end{tabular}

In the dendrogram, four groups have been recognized within the genus Artemisia. Species like A. chinensis, A. chamaemelifolia and A. tournefortiana were clustered in group 1. A. herba-alba, A. pontica, A. gmelinii and A. indica were placed in group 2. A. austriaca, A. scoparia, A. rutifolia, A. montana, A. campestris and A. vulgaris were designated in group 3 . The rest two species A. annua and A. maritima were placed in group 4 (Fig. 4).

The pollen morphological evolutions have the ability to develop more and more degenerative structures (Hayat et al., 2010). Few characters of pollen like, lobular pollen shape, arrangement dense spinules, broad spinule base, granular exine sculpture, large pollen size, thick exine and broad colpus width, are the plesiomorphic characteristics of Artemisia pollen. On the other hand, 
in apomorphic condition these pollen characteristics have ability to be transformed to oblate pollen, lose arrangement of spinules, without prominent spinule base, sinuolate exine sculpture, small pollen size and volume, reduced exine thickness and thin colpus.

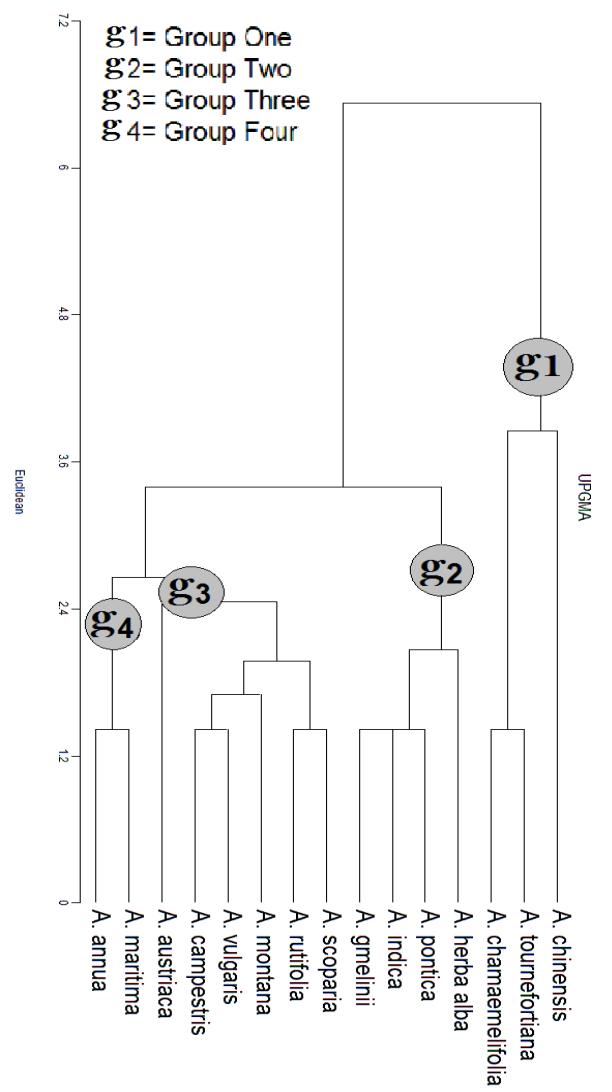

Fig. 4. Dendrogram based on cluster analysis of pollen micromorphological characters of different species of the genus Artemisia.

Studies authenticated one reason behind this evolution is the patterns of pollination from entomophily to anemophily. While, climate changing patterns with high latitude to low latitude during the relocation from North Temperate Zone and low evaluation moist regions during the glacial epoch are other major cause of this evolution in pollen of Artemisia (Jiang et al., 2005).

Our results are in accordance with the findings of Hayat et al. (2010) and Martin et al. (2003) who proposed pollen morphology as a diagnostic feature for Artemisia and recognized as an excellent taxonomic marker. However, our results are not in agreement with Jiang et al. (2005) suggesting that the grouping of Artemisia species based on their pollen morphology is very difficult task. We also propose that the arrangement patterns of spinules (dense/loose) are also a good taxonomic character for species delimitation.

This study concludes that the pollen characters of genus Artemisia could be taxonomically crucial traits for few species with in the genus. Together with the data from molecular studies, phytochemistry, karyology and phytogeography, the micromorpholigical traits of pollen can be useful for subgeneric classification of the genus Artemisia. 


\section{Acknowledgements}

The authors are obliged to the Higher Education Commission (HEC) of Pakistan and the Agricultural Experiment Station of the University of California, Davis USA for providing assistance to complete this research work. The authors are indebted to the International Islamic University Islamabad Pakistan and National University of Science and Technology Islamabad Pakistan for giving research facilities. The authors are thankful to Miss. Patricia (Pat) E. Kysar, CEMT, Staff Research Associate SRAIII University of California Davis California USA for her technical support throughout the scanning electron microscopy.

\section{References}

Bremer, K. 1994. Asteraceae. Cladistics and Classification. Portland, Timber Press.

Bremer, K. and Humphries, C.J. 1993. Generic Monograph of the Asteraceae-Anthemideae. Bull. Nat. His. Mus. London (Bot.) 23: 71-177.

Caramiello, R., Siniscalco, C. and Polini, V. 1989. Analyses aeroplaynologiques et phenologiquesd' Artemisia. Grana. 28: 105-113.

D'Andrea, S., Caramiello, R., Ghignone, S. and Siniscalco, C. 2003. Systematic studies on some of the Artemisia: biomolecular analysis. Pl. Biosyst. 137: 121-130.

Edward, L. 1994. Plesiomorphic and apomorphic pollen structure characteristics of Anthemideae (Asteroideae: Asteraceae). American J. Bot. 81: 648-657.

Garcia, S., McArthur, E.D., Pellicer, J., Sanderson, S.C., Vallès, J., and Garnatje, T. 2011. A molecular phylogenetic approach to western North America endemic Artemisia and allies (Asteraceae): untangling the sagebrushes. American J. Bot. 98: 638-653.

Ghafoor, A. 2002. Asteraceae (I) - Anthemideae. In: Ali S.I. and Qaiser M. (eds.) Flora of Pakistan, vol. 207. Karachi, University of Karachi and St. Louis, Missouri Botanical Garden.

Haghighi, A.R., Belduz, A.O., Vahed, M.M., Coskuncelebi, K. and Terzioglu, S. 2014. Phylogenetic relationships among Artemisia species based on nuclear ITS and chloroplast $p s b A$-trnH DNA markers. Biologia. 69: 834-839.

Hayat, M.Q., Ashraf, M., Khan, M.A., Yasmin, G., Shaheen, N. and Jabeen, S. 2010. Palynological study of the genus Artemisia (asteraceae) and its systematic Implications. Pak. J. Bot. 42: 751-763.

Hussain, A., Hayat, M.Q., Sahreen, S., Ain, Q.U. and Bokhari, S.A.I. 2017. Pharmacological promises of genus Artemisia (Asteraceae): a review. Proc. Pak. Acad. Sci: B. Life. Environ. Sci. 54: 265-287.

Hussain, A., Hayat, M.Q., Sahreen, S. and Bokhari, S.A.I. 2019a. Unveiling the foliar epidermal anatomical characteristics of genus Artemisia (Asteraceae) from northeast (Gilgit-Baltistan), Pakistan. Int. J. Agric. Biol. 21: 630-638.

Hussain, A., Potter, D., Kim, S., Hayat, M.Q. and Bokhari, S.A.I. 2019b. Molecular phylogeny of Artemisia (Asteraceae-Anthemideae) with emphasis on undescribed taxa from Gilgit-Baltistan (Pakistan) based on nrDNA (ITS and ETS) and cpDNA (psbA-trnH) sequences. Pl. Ecol. Evol. 152: 507-520.

Jiang L., Wang, Q., Ye, L. and Lin. Y.R. 2005. Pollen Morphology of Artemisia L. and its systematic significance. Wuhan Univ. J. Nat. Sci. 10: 448-454.

Kornkven, A.B., Watson, L.E. and Estes, J.R. 1998. Phylogenetic analysis of Artemisia section Tridentatae (Asteraceae) based on the sequences from the internal transcribed spacers (ITS) of nuclear ribosomal DNA. American J. Bot. 85: 1787-1795.

Kornkven, A.B., Watson L.E. and Estes, J.R. 1999. A molecular phylogeny of Artemisia section Tridentatae (Asteraceae) based on chloroplast DNA restriction site variation. Syst. Bot. 24: 69-84.

Kovach, W.L. 2007. MVSP-multivariate statistical package. Version 3.13. Kovach Computing Services, Pentraeth, Wales, UK.

Ling, Y.R. 1995. The new world Artemisia L. In: Hind, D.J.N., Jeffrey C. and Pope, G.V. (eds) Advances in Compositae systematics: 283-291. Royal Botanical Garden, Kew, UK. 
Lodari, C., Hattori, K. and Futsuhara, Y. 1989. Morphological difference on leaf surface and pollen grains in genus Artemisia. Japanese J. Breed. 39: 9-14.

Malik, S., Vitales, D., Hayat, M.Q., Korobkov, A.A., Garnatje, T. and Vallès, J. 2017. Phylogeny and biogeography of Artemisia subgenus Seriphidium (Asteraceae, Anthemideae). Taxon. 66: 934-952.

Mallick, P.K. 2015. Cytogenetical studies on some members of the family Asteraceae of Nepal (Unpublished doctoral dissertation). Central Department of Botany, Institute of Science and Technology, Tribhuvan University Kathmandu, Nepal.

Martin, J, Torrel, M., Korobkov, A.A. and Valles. J. 2003. Palynological features as systematic marker in Artemisia L. and related genera (Asteraceae, Anthemideae)-II: implications for subtribe Artemisiinae delimitation. Plant Biol. 5: 85-93.

Mbagwu, F.N. and Edeoga, H.O. 2006. Palynological studies on some Nigerian species of Vigna Savi. J. Biol. Sci. 6: 1122-1125.

Pellicer, J., Garcia, S., Canela, M.A., Garnatje, T., Korobkov, A.A., Twibell, J.D. and Vallès J. 2010. Genome size dynamics in Artemisia L. (Asteraceae): following the track of polyploidy. Pl. Biol.12: 820 830.

Perveen, A. and Qaiser, M. 2010. Pollen flora of Pakistan - Dipsacaceae LXVIII. Pak. J. Bot. 42: 2825-2827.

Pinar, N.M. and Donmez, E.O. 2000. Pollen morphology of some Turkish endemic Helichrysum Gaertner species (Compositae). Pak. J. Bot. 32: 295- 301.

Reitssma, T. 1970. Suggestions toward unification of descriptive terminology of angiosperm pollen grains. Rev. Paleobot. Palynol. 10: 39-60.

Riggins, C.W. and Seigler, D.S. 2012. The genus Artemisia (Asteraceae: Anthemideae) at a continental crossroads: Molecular insights into migrations, disjunctions, and reticulations among old and new world species from a Beringian perspective. Mol. Phylo. Evol. 64: 471-490.

Sachdeva, S.K. and Malik, C.P. 1986. Experimental Plant Taxonomy. Kalyani Publications, New Delhi.

Sanz, M., Vilatersana, R., Hidalgo, O., Garcia-Jacas, N., Susanna, A., Schneeweiss, G.M., and Vallès, J. 2008. Molecular phylogeny and evolution of floral characters of Artemisia and allies (Anthemideae, Asteraceae): Evidence from nrDNA ETS and ITS sequences. Taxon. 57: 66-78.

Scotland, R.W. Olmstead, R.G. and Bennett, J.R. 2003. Phylogeny Reconstruction: The Role of Morphology. Syst. Biol. 52: 539-548.

Shultz, L.M. 2009. Monograph of Artemisia subgenus Tridentatae (Asteraceae-Anthemideae). Syst. Bot. Monog. 89: 1-131.

Stuessy, T.F. 2009. Plant Taxonomy: the systematic evaluation of comparative data. Columbia University Press, $568 \mathrm{pp}$.

Terra, D.A., Amorim, L., Catanho, M.T.J., Fonseca, A., Santos-Filho, S.D., Brandão-Neto, J., Medeiros, A. and Bernardo-Filho, M. 2007. Effect of an extract of Artemisia vulgaris L. (Mugwort) on the in vitro labeling of red blood cells and plasma proteins with technetium- 99m. Braz. Arc. Biol. Tech. 50: 123128.

Torrell, M. Garcia-Jacas, N., Susanna, A. and Valles, J. 1999. Infrageneric phylogeny of the genus Artemisia L. (Asteraceae, Anthemidae) based on nucleotide sequences of nuclear ribosomal DNA internal transcribed spacers (ITS). Taxon. 48: 721-736.

Valles, J., Suarez M. and Seoane, J.A. 1987. Estudio Palinologico de las especies iberico-baearicas de las secciones Artemisia Seriphedium Bess. Del genero Artemisia L. Acta Salmaticensia Ciencias. 65: 167174.

Valles, J. and McArthur, E.D. 2001. Artemisia systematics and phylogeny: cytogenetic and molecular insights. In: McArthur, E.D., and Fairbanks, D.J. (Eds), Proc. Shrubland Ecosystem Genetics and Biodiversity. pp: 67-74. June 13-15, 2000. US Department of Agriculture Forest Service, Rocky Mountain Research Station, Provo, UT Ogden, USA.

Vallès, J., Torrell, M., Garnatje, T., Garcia-Jacas, N., Vilatersana, R. and Susanna, A. 2008. The Genus Artemisia and its allies: phylogeny of the subtribe Artemisiinae (Asteraceae, Anthemadea) based on nucleotide sequences of nuclear ribosomal DNA internal transcribed spacers (ITS). Pl. Biol. 5: 274-284. 
Vezey E.L., Watson, L.E., Skvarla, J.J. and Estes, J.R. 1994. Plesiomorphic and apomorphic pollen structure characteristics of Anthemideae (Asteroideae: Asteraceae). American J. Bot. 81: 148-657.

Watson, L.E., Bates, P.L., Evans, T.M., Unwin, M.M. and Estes, J.R. 2002. Molecular phylogeny of Subtribe Artemisiinae (Asteraceae), including Artemisia and its allied and segregate genera. BMC Evol. Biol. 2: 17-29.

Wodehouse, R.P. 1926. Pollen grain morphology in the classification of the Anthemideae. Bull. Torrey Club. 53: 479-485.

Zafar, M., Ahmad, M. and Khan, M.A. 2007. Palynology of family Asteraceae from Flora of RawalpindiPakistan. Int. J. Agric. Biol. 1: 156-161.

(Manuscript received on 2 February, 2018; revised on 10 December, 2019) 